\title{
Optimising the management of even-aged Pinus sylvestris L. stands in Galicia, north-western Spain
}

\author{
María PASAlodos-TATo*, Timo PUKKala \\ University of Joensuu, Faculty of Forestry, PO Box 111, 80101 Joensuu, Finland
}

(Received 14 December 2006; accepted 27 March 2007)

\begin{abstract}
The study developed management instructions for even-aged Pinus sylvestris stands in Galicia (north-western Spain). Although these stands are highly productive, no silvicultural management schedules have been proposed so far for them on the basis of systematic analyses. This study used data from 2160 optimisation runs to develop the management instructions. Land expectation value was used as the objective function. Different prices of timber assortments were considered and the discounting rate was varied from 0.5 to $5 \%$. The method employed to find the optimal management schedules of stands was the combination of a stand simulator and an optimisation algorithm. The simulator uses an earlier growth and yield model for Pinus sylvestris in Galicia to predict the future development of the stand with a given management schedule while the optimisation algorithm seeks the best management schedule among all the possible alternatives. The results show that optimal rotation lengths vary widely between 42 and 170 years, high discounting rates and good site quality resulting in the shortest rotations. Four thinnings were found to be suitable for all sites and discounting rates. With discounting rates higher than $1 \%$ the commercial thinnings should gradually decrease the stand basal area towards the end of the rotation.
\end{abstract}

growth and yield model / optimal management / Scots pine / simulation

Résumé - Optimisation de la gestion des peuplements équiennes de Pinus sylvestris L. en Galice dans le Nord-ouest de l'Espagne. Cette étude développe des instructions de gestion pour des peuplements de Pinus sylvestris en Galice (Nord-ouest de l'Espagne). Bien que ces peuplements soient hautement productifs, aucun plan de gestion sylvicole basé sur des analyses sytématiques, n'a jusqu'ici été proposé. Cette étude utilise les données de 2160 séquences d'optimisation pour développer des instructions de gestion. Une attente de valeur foncière a été utilisée comme fonction-objectif. Différents prix de lots de bois ont été pris en compte et le taux d'escompte a varié de 0,5 à $5 \%$. La méthode employée pour évaluer le programme optimal de gestion a été la combinaison d'un simulateur de croissance de peuplement et d'un algorithme d'optimisation. Le simulateur utilise un modèle existant de croissance et de production de Pinus sylvestris en Galice pour prédire le développement du peuplement pour un plan de gestion tandis que l'algorithme d'optimisation recherche le meilleur plan gestion parmi toutes les alternatives possibles. Les résultas montrent que la durée optimale de rotation varie entre 42 et 170 ans. Des taux d'escompte élevés et des stations de bonne qualité permettent les révolutions les plus rapides. Quatre éclaircies semblent appropriées pour toute les stations et tous les taux d'escompte. Avec des taux d'escompte plus élevés que $1 \%$ les éclaircies commerciales doivent abaisser graduellement la surface terrière des peuplements vers la fin de la rotation.

modèle de croissance et de production / gestion optimale / Pinus sylvestris / simulation

\section{INTRODUCTION}

Galicia, located in north-western Spain, is one of the most important regions in Spain from the point of view of forestry production. Galicia covers an area of nearly three million hectares, of which $69.7 \%$ are classified as forest land. Of the forests land, $48.2 \%$ are wooded forest land with a canopy cover higher than $20 \%$. Galicia produces $40 \%$ of the total harvested timber volume in Spain. The average growth is $8.5 \mathrm{~m}^{3} \mathrm{ha}^{-1}$ year $^{-1}$. However, it is possible to reach $30 \mathrm{~m}^{3} \mathrm{ha}^{-1}$ year $^{-1}$ for eucalypts on the best sites [6].

Pinus sylvestris $\mathrm{L}$. is the second-most important conifer in Galicia, after Pinus pinaster Ait., in terms of area covered and the third-most productive, after Pinus pinaster Ait. and Pinus radiata $\mathrm{D}$. Don $[6,38]$. P. sylvestris stands have an annual average harvested volume of approximately $78000 \mathrm{~m}^{3}[39]$ and cover an area of 63195 ha, which mainly occur in pure stands but also mixed with $P$. radiata and $P$. pinaster $[6,38]$. Most stands are in the provinces of Lugo and Ourense and they are

* Corresponding author: maria.pasalodos@joensuu.fi under communal ownership but managed, in most cases, by the Regional Forest Service.

The origins of the present $P$. sylvestris stands in Galicia date back to the great reforestation effort that took place in Spain in the 1940's by the Spanish administration. The stands are therefore younger than 60 years, half of them are $30-55$ years old. Because the rotation length has been set to 70-80 years in good sites [21,32] no clear fellings have been carried out yet. No silvicultural treatments have been done either, except pruning up to two meters in order to improve accessibility to the stands and to reduce the risk of forest fire [2]. The importance of pre-commercial thinnings in the development of $P$. sylvestris stands has been proved in several studies $[17,26,34,37]$. Controlling stand density by thinnings has been a major tool in increasing individual tree growth and regulating wood quality [20]. Thinning reduces stand growth proportionally to thinning intensity $[18,24]$. Thinnings do not increase the total volume increment per unit area (e.g. [14,23]) but they distribute the available resources among the remaining trees, shifting the distribution of growth to larger, more 
highly valued trees $[5,19,29]$. Therefore, the growth reduction per unit area may be compensated for by larger stem diameters and earlier income from thinnings [20]. However, due to the belief that thinning treatments are non-profitable, lack of practical experience with this species and lack of modern tools to analyse different management options, thinning treatments have not been routinely done in Pinus sylvestris stands in Galicia.

It was only some years ago when the Galician Forest Service started to thin Scots pine stands. Nevertheless, these experiments have not yet resulted in any management instructions. In order to improve the management of Galician P. sylvestris stands, the University of Santiago de Compostela established a net of permanent plots that provide data to develop yield models and management tools. The most important output of this research is the dynamic growth and yield model by Dieguez-Aranda et al. [11]. This model allows managers to simulate any management schedule in a given stand, providing very helpful information for the decision making process.

Once this tool is developed, the next step is to find that management alternative which best fits to the interests of forest landowner. Many objectives could be considered when evaluating management alternatives [30] like maximising economic benefits [25,35], maximising the multiple services of the forest [7], maximising the economic benefit considering the risk of fire [13], maximising the combined benefit from timber and mushroom harvests [9], maximising the economic benefit taking $\mathrm{CO}_{2}$-capture into account [8], or integrating biodiversity and recreation in the evaluation [4].

In the present study the aim was to find out the management schedule that maximises the economic benefits, expressed in terms of land expectation value, at the stand level. This is because the stands are plantations established for wood production purposes. The method employed in this study has already been used successfully in several other studies (see e.g. [16] for references) and consists of the combination of a stand simulator and an optimisation algorithm. In Spain this method has been employed in the optimisation of the management of evenaged [25] and uneven-aged $P$. sylvestris stands in north-east Spain [35].

Using the results of the performed optimisations we developed regression models for the optimal rotation length and preand post-thinning basal area. The purpose was to develop a tool that helps forest managers in decisions concerning the rotation length, and the timing and intensity of thinnings. By using these regression models and diagrams based on them, the forest manager can see when and to which density the stand should be thinned or whether the stand is economically mature for clear-felling. These models for the optimal management are much easier to use in forestry practice than sophisticated optimisation algorithms.

\section{MATERIALS AND METHODS}

The stand level offers the first meaningful level of decision making, and the results obtained for the stand level management can be used as guidelines in forest level planning [36]. To find out how these guidelines are related to stand characteristics and economic parameters, many optimisations were performed with different values of these variables. Site index and stand density were varied so as to cover the whole range of variation existing in P. sylvestris stands in Galicia. Another set of analysed variables were economic parameters, namely timber prices, and discounting rate. The growth model simulates the outcomes of management alternatives and the optimisation algorithm finds out the optimal alternative for a given set of stand characteristics and economic parameters.

\subsection{Growth and yield model}

To simulate stand development in different management schedules, we used the model of Dieguez-Aranda et al. [11] for even-aged P. sylvestris stands in Galicia. In the model developed by DieguezAranda et al. [11] the initial stand is defined by four state variables: stand age, dominant height, number of trees per hectare and stand basal area. Age and dominant height determine the site index (dominant height at 40 years). The model uses three transition functions to provide the stand state at any point of time. Moreover, the model set includes a function for predicting the initial stand basal area, and it can be used to establish the starting basal area for the simulation. This alternative should only be used when no field-assessed basal area is available, as was the case in the present study.

The model for the initial stand basal area is [10]:

$$
G=\exp (-1.96989-19.2186 / T+0.51707 \ln (N)+0.944829 \ln (H))
$$

where $G$ is stand basal area $\left(\mathrm{m}^{2} \mathrm{ha}^{-1}\right), T$ is stand age (years), $N$ is number of trees per hectare and $H$ is dominant height (m). Dominant height $\left(\mathrm{H}_{2}\right)$, number of trees per hectare $\left(\mathrm{N}_{2}\right)$ and stand basal area $\left(G_{2}\right)$ at certain age $T_{2}$ are predicted from the following equations [11]:

$$
\begin{gathered}
H_{2}=\frac{51.39191}{1-\left(1-51.39191 / H_{1}\right)\left(T_{1} / T_{2}\right)^{1.276885}} \\
N_{2}=\left(N_{1}^{-1.5896}+1.1 \cdot 10^{-12} S I\left(T_{2}^{3.3079}-T_{1}^{3.3079}\right)\right)^{-1 / 1.5896} \\
G_{2}=92.39641\left(\frac{G_{1}}{92.39641}\right)^{\left(\frac{T_{1}}{T_{2}}\right)^{1.368563}}
\end{gathered}
$$

where subscript 1 refers to the situation at stand age $T_{1}$. SI is site index (dominant height at 40 years, expressed in $\mathrm{m}$ ). If there is a cutting treatment at age $T_{2}$, the diameter distribution of trees (parameters of the Weibull function) is predicted with the method of moments (see [11]). This method needs the variance of diameter. It is predicted from:

$$
V A R=D_{q}^{2}-\bar{d}^{2}
$$

where $D_{q}$ is quadratic mean diameter $(\mathrm{cm})$ obtained from

$$
D_{q}=\sqrt{40000 / \pi \times G_{2} / N_{2}} .
$$

The mean diameter is predicted from the following equation

$$
\bar{d}=D_{q}-\exp \left(-1.2942+0.000187 N_{2}+0.0363 H_{2}\right) .
$$

The Weibull distribution is used to calculate the number of trees per hectare in 1-cm diameter classes. The simulation of thinnings is based on these frequencies. Both systematic and low thinnings can be simulated. Systematic thinnings remove an equal percentage from every 
diameter class. When a low thinning is simulated, the remaining number of trees in diameter class $i\left(n_{i}\right)$ is calculated as follows:

$$
n_{i}=N_{\text {before }} L\left[\left(F\left(d_{i}\right)^{1 / L}-F\left(d_{i-1}\right)^{1 / L}\right]\right.
$$

where $N_{\text {before }}$ is the number of trees per hectare before low thinning, $L$ is low-thinning intensity expressed as one minus the proportion of removed trees $\left(1-N_{\text {removed }} / N_{\text {before }}\right)$ and $F(d)$ stands for Weibull distribution function (showing the cumulative frequency at diameter $d$ ).

The volumes of the removed trees are calculated by the taper model of Dieguez-Aranda et al. [11], which is based on the function proposed by Fang et al. [12]. The taper model is used to calculate the stem volume up to the following top diameters: 35,18 and $7 \mathrm{~cm}$. The timber assortments therefore correspond to the following over-bark stem diameters: (I) $d \geq 35 \mathrm{~cm}$; (II) $35 \mathrm{~cm}>d \geq 18 \mathrm{~cm}$; and (III) $18 \mathrm{~cm}>d \geq 7 \mathrm{~cm}$. The following minimum piece lengths were required: (I) $3.0 \mathrm{~m}$; (II) $2.5 \mathrm{~m}$; and (III) $1.0 \mathrm{~m}$. If the piece was shorter, the volume was moved to the next (with a smaller minimum top diameter) timber assortment.

\subsection{Objective function}

The economic performance was used to select the optimal treatment schedule for a stand. An appropriate measure of economic performance is the land expectation value (LEV), the present value of all future harvests and other operations including the opportunity cost of the growing stock. The LEV is defined as the net present value (NPV) of all future net incomes. The NPV of all the management operations during a rotation, discounted to the beginning of the rotation is:

$$
N P V=\sum_{t=0}^{R} \frac{C F_{t}}{(1+i)^{t}}
$$

where $C F$ is the net cash flow in year $t, i$ is discounting rate and $R$ is rotation length (years). The $N P V$ for an infinite number of rotations is known as the land expectation value, and can be expressed as:

$$
L E V=\frac{N P V}{1-\frac{1}{(1+i)^{R}}}
$$

A penalty function was added to the objective function to avoid too heavy thinnings that can jeopardize the stability of the stand. A thinning intensity higher than $30 \%$ was assumed to make the stand sensitive to wind throw and other damages. Therefore, the eventual objective function $(O F)$ which was maximised was:

$$
\begin{gathered}
O F=L E V-\sum_{k=1}^{K} \text { Penalty }_{k} \\
\text { Penalty }_{k}=\left\{\begin{array}{l}
0 \text { if } H \%_{k} \leqslant 30 \\
10000 \frac{H \%_{k}-30}{70} \text { if } H \%_{k}>30
\end{array}\right.
\end{gathered}
$$

where $H \%_{k}$ is thinning intensity in percent of removed stand basal area in thinning $k$ and $K$ is the number of thinnings. According to the penalty function, the penalty of harvesting too much at a time increases from 0 to $10000 € \mathrm{ha}^{-1}$ when the harvest percentage increases from 30 to 100 .

\subsection{Decision variables}

A management schedule is defined with a set of controllable variables, called as decision variables (DV). Optimising the management schedule means finding the optimal values for DVs [28]. The simulated thinnings are combinations of systematic and low thinning. Because the number of thinnings is not a continuous variable, schedules with different numbers of thinnings are to be treated as separate optimization problems [22]. In this study, the number of thinnings was fixed at four since four thinnings often produced the highest LEV, and was never much worse than the best number of thinnings.

The management regime was specified by the number of thinnings and the following DVs:

- For the first thinning

- Stand age;

- Percentage of systematic thinning ( $\%$ of number of trees);

- Percentage of low thinning ( $\%$ of trees removed after systematic thinning).

- For the other thinnings

- Number of years since the previous thinning;

- Percentage of systematic thinning (\% of number of trees);

- Percentage of low thinning ( $\%$ of trees removed after systematic thinning).

- For final felling

- Number of years since the last thinning.

The number of optimized decision variables was therefore $3 \times N_{\text {thin }}+1$ where $N_{\text {thin }}$ is the number of thinnings (i.e. 13 DVs with four thinnings).

\subsection{Optimisation method}

The direct search method of Hooke and Jeeves [15] was used as the optimisation algorithm. This method uses a form of coordinate optimization and does not require explicit evaluation of any partial derivative of the objective function (e.g. [3]). The direct search method of Hooke and Jeeves consists of the search for the best solution of a problem, by comparing each new trial solution with the best obtained up to that time. This search has two components, the exploratory search and the pattern search. The exploratory search-move looks for the best solution in the direction of one coordinate axis (decision variable) at a time, and the pattern search uses the information provided by exploratory search to move in directions other than coordinate axes. For a given base point, the exploratory search examines points around that base point in the direction of the coordinate axes. The pattern search moves the base point in the direction defined by the given (current) base point and the best point found in exploratory search.

The convergence of this method to the global optimum is not guaranteed with the objective functions which are neither convex nor differentiable [22]. Therefore, all the optimisations were repeated three times, each run starting from the best of 20 random combinations of decision variables, except the first one, which started from a userdefined starting point. The random values were uniformly distributed over a user-specified range. The following ranges were used ( $I$ is the mean thinning interval calculated as follows: $I=$ (Initial guess for rotation length $(R)$ - Age of initial stand)/ (Number of thinnings +1$)$ ):

- Year of the first thinning: (Age of initial stand, Age of initial stand $+2 I$ ); 
- Other cutting intervals: $(5,2 I)$;

- Percentage of basal area removed systematically in a thinning: $(0,40)$;

- Percentage of basal area removed as low thinning after completing the systematic thinning: $(0,40)$.

The guess for the rotation age $(R)$ was 60 . The ranges obtained in this way only concerned the random searches in the beginning of each direct search: the direct search was allowed to go outside these ranges. The initial step-sizes in altering the values of DVs in the direct search were 0.1 times the above ranges. The step size was gradually reduced during the direct search, and the search was stopped when the step size for all DVs was less than 0.01 times the initial step (convergence criterion).

\subsection{Initial stands}

The dynamic growth and yield model used in this study needs four initial state variables to begin the simulation. These variables are stand age, dominant height, number of trees per hectare and stand basal area. Stand age and dominant height define the site index which is dominant height at 40 years. In this study the age of the initial stands was fixed at 10 years, and the initial dominant height was calculated from stand age and site index. Four different site indices were chosen, 6, 12, 18 and $24 \mathrm{~m}$ at 40 years. The stand densities were 1000, 1500, 2000 and 2500 trees per ha. Higher densities were not used due to the lack of evidence of their use in the Galician region. The third state variable that needs to be defined is the stand basal area. It was calculated in the simulator using Equation (1). Once all the variables were defined there were sixteen different initial stands which differed in terms of site index and planting density (4 site indices times 4 planting densities).

\subsection{Economic parameters}

The economic parameters needed for calculating the LEV were discounting rate, treatment costs and timber prices. The cost parameters included regeneration and tending costs, and harvesting costs. For timber price data, different sources were consulted, such as the Association of Galician Private Forest Owners and the Forest Administration of Galicia. The data obtained were very similar to the ones used in Rojo et al. [33], and therefore these prices were used. The base prices were $90 € \mathrm{~m}^{-3}$ for grade I timber (top diameter $\geq 35 \mathrm{~cm}$ ), $50 € \mathrm{~m}^{-3}$ for grade II timber $(\geq 18 \mathrm{~cm})$ and $18 € \mathrm{~m}^{-3}$ for grade III timber $(\geq 7 \mathrm{~cm})$. To cover the possible variation in timber markets, $20 \%$ variation was generated with a limitation that a better assortment must always have a better price. This resulted in the following timber prices: grade I: 120,90 and $65 € \mathrm{~m}^{-3}$; grade II: 65,50 and $35 € \mathrm{~m}^{-3}$; grade III: 24,18 and $12 € \mathrm{~m}^{-3}$. This gives 27 combinations, which means that every optimisation was repeated with 27 different sets of timber prices.

The Galician Forestry Administration was consulted for silvicultural costs (Tab. I). The tending cost was assumed to be a linear function with a constant part representing the cost of land preparation and the variable part representing the plantation cost per tree:

$$
\text { RCost }=500+1 \times N
$$

where $R$ Cost is regeneration cost ( $€ \mathrm{ha}^{-1}$ ) and $N$ is the number of seedings per hectare.
Table I. Years and costs of tending operations in different sites. $N$ is the number of planted trees per hectare.

\begin{tabular}{|c|c|c|}
\hline Year & Operation & Cost $(€ /$ ha $)$ \\
\hline \multicolumn{3}{|c|}{$S I=6 \mathrm{~m}$} \\
\hline 0 & Regeneration & $500+1 N$ \\
\hline 2 & Cleaning & 150 \\
\hline 4 & Cleaning & 150 \\
\hline 40 & Pruning & 200 \\
\hline \multicolumn{3}{|c|}{$S I=12 \mathrm{~m}$} \\
\hline 0 & Regeneration & $500+1 N$ \\
\hline 2 & Cleaning & 150 \\
\hline 4 & Cleaning & 150 \\
\hline 20 & Pruning & 200 \\
\hline 45 & Pruning & 200 \\
\hline \multicolumn{3}{|c|}{$S I=18 \mathrm{~m}$} \\
\hline 0 & Regeneration & $500+1 N$ \\
\hline 2 & Cleaning & 150 \\
\hline 4 & Cleaning & 150 \\
\hline 15 & Pruning & 200 \\
\hline 30 & Pruning & 200 \\
\hline \multicolumn{3}{|c|}{$S I=24 \mathrm{~m}$} \\
\hline 0 & Regeneration & $500+1 N$ \\
\hline 2 & Cleaning & 150 \\
\hline 4 & Cleaning & 150 \\
\hline 10 & Pruning & 200 \\
\hline 20 & Pruning & 200 \\
\hline
\end{tabular}

The management schedule of a stand depends on the quality of the site [33] so that stands with higher site indices need to be pruned earlier than stands with poorer site indices. Accordingly, a different tending schedule was used for every site index (Tab. I).

The harvesting cost was calculated from (based on [1]):

$$
H C o s t=E C o s t+V\left[F C o s t+\left(78(S+3.3)^{0.30477} / v_{\text {mean }}^{0.972}\right) / 167\right]
$$

where HCost is harvesting cost $\left(€ \mathrm{ha}^{-1}\right)$, ECost is entry cost $\left(€ \mathrm{ha}^{-1}\right)$, $V$ is the total harvested volume $\left(\mathrm{m}^{3} \mathrm{ha}^{-1}\right)$, FCost is forwarding cost ( $\left.€ \mathrm{~m}^{-3}\right), S$ is slope (\%), and $v_{\text {mean }}$ is the mean volume of harvested trees $\left(\mathrm{m}^{3}\right)$. It was assumed that the entry cost of moving the machinery to the forest (ECost) is $200 € \mathrm{ha}^{-1}$. The forwarding cost was assumed to be $5 € \mathrm{~m}^{-3}$ and the slope was taken as $20 \%$.

Several discounting rates were used $(0.5 \%, 1 \%, 2 \%, 3 \%$ and $5 \%)$ in order to cover varying economic conditions. Each of the sixteen initial stands was optimised for every combination of discounting rates and timber prices $(5 \times 27=135$ optimisations for each of the 16 initial stands, i.e., altogether 2160 optimisations).

\subsection{Modelling rotation length and thinning moment}

Optimisation found the best management schedule for each initial stand with every combination of timber prices and discounting rates. Preliminary optimisations were done for different numbers of thinnings (0-6). The results showed that, for all site indices, four 

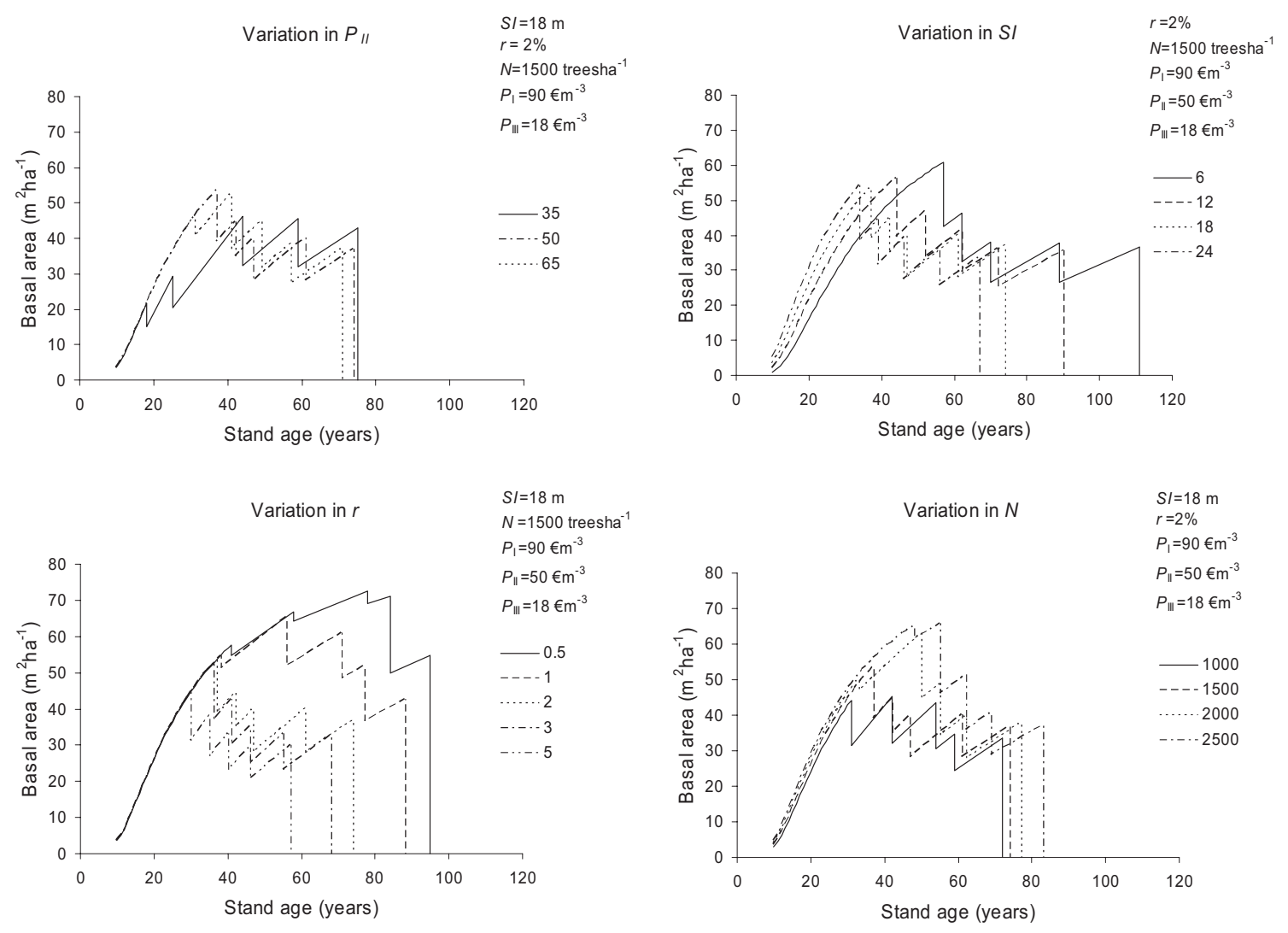

Figure 1. Examples of optimisations used as modelling data.

is the best overall number of thinnings; often it was the best, and when it was not, it gave land expectation values nearly as high as the best number of thinnings. Therefore, the 2160 optimal management schedules with four thinnings were used to model the dependence of rotation length and thinning on stand characteristics (planting density and site index) and economic parameters (discounting rate and timber prices). Models were developed for rotation length, and for the stand basal area of a pre- and post-thinning stand. The SPSS 14.0 software was used to construct these models. Figure 1 shows examples of optimisations that were used as modelling data.

\section{RESULTS}

\subsection{Rotation length}

After analysing several combinations with different predictors supposed to affect the rotation length, and considering that all the predictors had to be significant at the 0.0005 level, the model obtained for the rotation length was the following:

$$
\begin{aligned}
\ln (R)= & \mathrm{a}_{0}+\mathrm{a}_{1} \ln (S I)+\mathrm{a}_{2} \ln (N)+\mathrm{a}_{3} \ln (r) \\
& +\mathrm{a}_{4} P_{\mathrm{II}}+\mathrm{a}_{5}\left(P_{\mathrm{I}} \times P_{\mathrm{II}}\right)+\mathrm{a}_{6}\left(P_{\mathrm{I}} \times r\right)
\end{aligned}
$$

where $R$ is rotation length (years), $S I$ is site index (m), $N$ is the planting density (number of trees per hectare), $r$ is discounting rate (\%) and $P_{i}$ is the price of grade $i$ (I or II) in $€ \mathrm{~m}^{-3}$. Some of the predictors were products of initial predictors $\left(P_{\mathrm{I}} \times P_{\mathrm{II}}\right.$ and $\left.P_{\mathrm{I}} \times r\right)$ describing interactions between them.

All variables present in the model were significant according to the $t$ test $(p<0.0005$, Tab. II). Although other variables were tested, such as the price of grade III, and several combinations of variables, the model in Equation (14) was the one that gave the best results with $R^{2}$ of 0.952 and a standard error of 0.064 . The predictors of the model can be divided into two groups: variables that describe the stand, and economic variables. The first group includes site index, which defines the quality of the site, and planting density. The economic parameters comprise discounting rate and the prices of timber grades I and II.

Several conclusions can be extracted from this model, most of them being what one would expect. Firstly, higher site indices have shorter rotation lengths. Secondly, the higher is the number of trees per hectare the longer are the optimal rotation lengths. Thirdly, increasing discounting rate shortens optimal rotation lengths (Fig. 2). The model also describes interactions between variables. The model suggests that increasing price of grade II $(18 \mathrm{~cm}<d \leq 35 \mathrm{~cm})$ shortens optimal rotations, which is logical [27]. However, the effect depends on the price of grade I $(d>35 \mathrm{~cm})$ so that improving $P_{\mathrm{I}}$ partly cancels the effect of $P_{\mathrm{II}}$. The effect of the price of grade I depends on discounting rate: with low rates a high value of price I leads to longer optimal rotation lengths but the opposite is true with high rates (Fig. 3). 
Table II. Regression coefficients of Equation (14), (15) and (16), their standard errors (S.E.) and statistical significance.

\begin{tabular}{|c|c|c|c|c|c|}
\hline Variable & Parameter & Coefficient & S.E. & $t$ statistic & Significance $(p)$ \\
\hline \multicolumn{6}{|c|}{ Equation (14) } \\
\hline Constant & $\mathrm{a}_{0}$ & 4.391 & 0.032 & 138.754 & $<0.0005$ \\
\hline $\ln (S I)$ & $a_{1}$ & -0.394 & 0.003 & -147.843 & $<0.0005$ \\
\hline $\ln (N)$ & $\mathrm{a}_{2}$ & 0.195 & 0.004 & 47.759 & $<0.0005$ \\
\hline $\ln (r)$ & $a_{3}$ & -0.101 & 0.004 & -23.178 & $<0.0005$ \\
\hline$P_{\mathrm{II}}$ & $\mathrm{a}_{4}$ & -0.009 & 0.000 & -51.636 & $<0.0005$ \\
\hline$P_{\mathrm{I}} \times P_{\mathrm{II}}$ & $a_{5}$ & $5.38 \times 10^{-5}$ & 0.000 & 34.498 & $<0.0005$ \\
\hline$P_{\mathrm{I}} \times r$ & $\mathrm{a}_{6}$ & -0.001 & 0.000 & -25.697 & $<0.0005$ \\
\hline \multicolumn{6}{|c|}{ Equation (15) } \\
\hline Constant & $a_{0}$ & -7.901 & 0.096 & -82.388 & $<0.0005$ \\
\hline SI & $a_{1}$ & 0.083 & 0.001 & 90.242 & $<0.0005$ \\
\hline $\ln (T)$ & $a_{2}$ & 3.110 & 0.018 & 173.338 & $<0.0005$ \\
\hline$T \times r$ & $a_{3}$ & -0.002 & 0.000 & -34.645 & $<0.0005$ \\
\hline$P_{\mathrm{I}}$ & $a_{4}$ & 0.006 & 0.000 & 24.398 & $<0.0005$ \\
\hline$P_{\mathrm{I}} \times P_{\mathrm{II}}$ & $a_{5}$ & $-2.98 \times 10^{-5}$ & 0.000 & -8.689 & $<0.0005$ \\
\hline Fst & $a_{6}$ & 2.337 & 0.013 & 115.100 & $<0.0005$ \\
\hline Snd & $a_{7}$ & 1.548 & 0.012 & 66.948 & $<0.0005$ \\
\hline Trd & $a_{8}$ & 0.776 & 0.000 & 24.398 & $<0.0005$ \\
\hline \multicolumn{6}{|c|}{ Equation (16) } \\
\hline Constant & $a_{0}$ & -20.719 & 1.982 & -10.452 & $<0.0005$ \\
\hline SI & $a_{1}$ & 0.132 & 0.016 & 8.054 & $<0.0005$ \\
\hline $\ln (T)$ & $a_{2}$ & 3.717 & 0.485 & 7.657 & $<0.0005$ \\
\hline$G_{\text {before }}$ & $a_{3}$ & 0.830 & 0.010 & 84.062 & $<0.0005$ \\
\hline$T \times r$ & $\mathrm{a}_{4}$ & -0.025 & 0.001 & -28.113 & $<0.0005$ \\
\hline$P_{\mathrm{I}}$ & $a_{5}$ & 0.039 & 0.003 & 12.002 & $<0.0005$ \\
\hline$P_{\mathrm{I}} \times P_{\mathrm{II}}$ & $a_{6}$ & $-2.81 \times 10^{-4}$ & 0.000 & -6.337 & $<0.0005$ \\
\hline Fst & $a_{7}$ & 4.162 & 0.380 & 10.954 & $<0.0005$ \\
\hline Snd & $a_{8}$ & 3.039 & 0.092 & 11.212 & $<0.0005$ \\
\hline $\operatorname{Trd}$ & $\mathrm{a}_{9}$ & 1.562 & 0.182 & 8.585 & $<0.0005$ \\
\hline
\end{tabular}

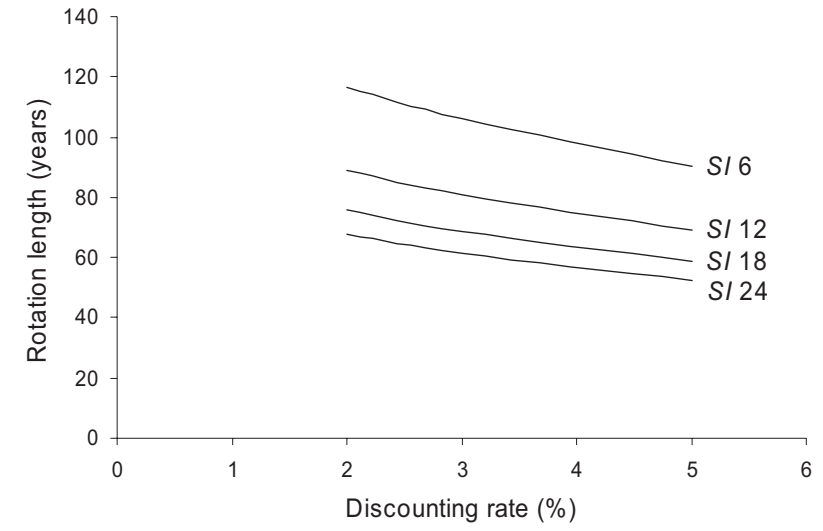

Figure 2. Effect of discounting rate and site index $(S I)$ on the rotation length when planting density is $2000 \mathrm{ha}^{-1}$ and prices for grades I and II are 90 and $50 € \mathrm{~m}^{-3}$, respectively.

The shortest rotations are obtained when the price of grade I and the number of trees per hectare are low $\left(65 € \mathrm{~m}^{-3}\right.$ and 1000 trees per hectare, respectively) and the price of grade II and discounting rate are high $\left(65 € \mathrm{~m}^{-3}\right.$ and $\left.5 \%\right)$.

\subsection{Pre- and post-thinning basal area}

The models obtained for stand basal area before and after a thinning treatment in the optimal management schedules were:

$$
\begin{aligned}
\sqrt{G_{\text {before }}} & =\mathrm{a}_{0}+\mathrm{a}_{1} S I+\mathrm{a}_{2} \ln (T)+\mathrm{a}_{3}(T \times r) \\
& +\mathrm{a}_{4} P_{\mathrm{I}}+\mathrm{a}_{5}\left(P_{\mathrm{I}} \times P_{\mathrm{II}}\right)+\mathrm{a}_{6} F s t+\mathrm{a}_{7} S n d+\mathrm{a}_{8} \operatorname{Tr} d \\
G_{\text {after }}= & \mathrm{a}_{0}+\mathrm{a}_{1} S I+\mathrm{a}_{2} \ln (T)+\mathrm{a}_{3} G_{\text {before }}+\mathrm{a}_{4}(T \times r) \\
& +\mathrm{a}_{5} P_{\mathrm{I}}+\mathrm{a}_{6}\left(P_{\mathrm{I}} \times P_{\mathrm{II}}\right)+\mathrm{a}_{7} F s t+\mathrm{a}_{8} S n d+\mathrm{a}_{9} \operatorname{Tr} d
\end{aligned}
$$

where $T$ is stand age expressed in years. The $R^{2}$ for Equation (15) was 0.866 and the standard error was 0.357. For Equation (16) the $R^{2}$ was 0.897 and the standard error was 4.570. All the predictors were significant according to the $t$ test $(p<0.0005)$. Furthermore, no significant multicollinearity was observed between the variables in the models.

Since the basal area of pre- and post-thinning stand was influenced by the number of the thinning, dummy variables $F s t$, Snd and Trd, which represent the first, second and third thinning, respectively, were included in the models. A value of 1 indicates "presence". For example, Fst is equal to one when 

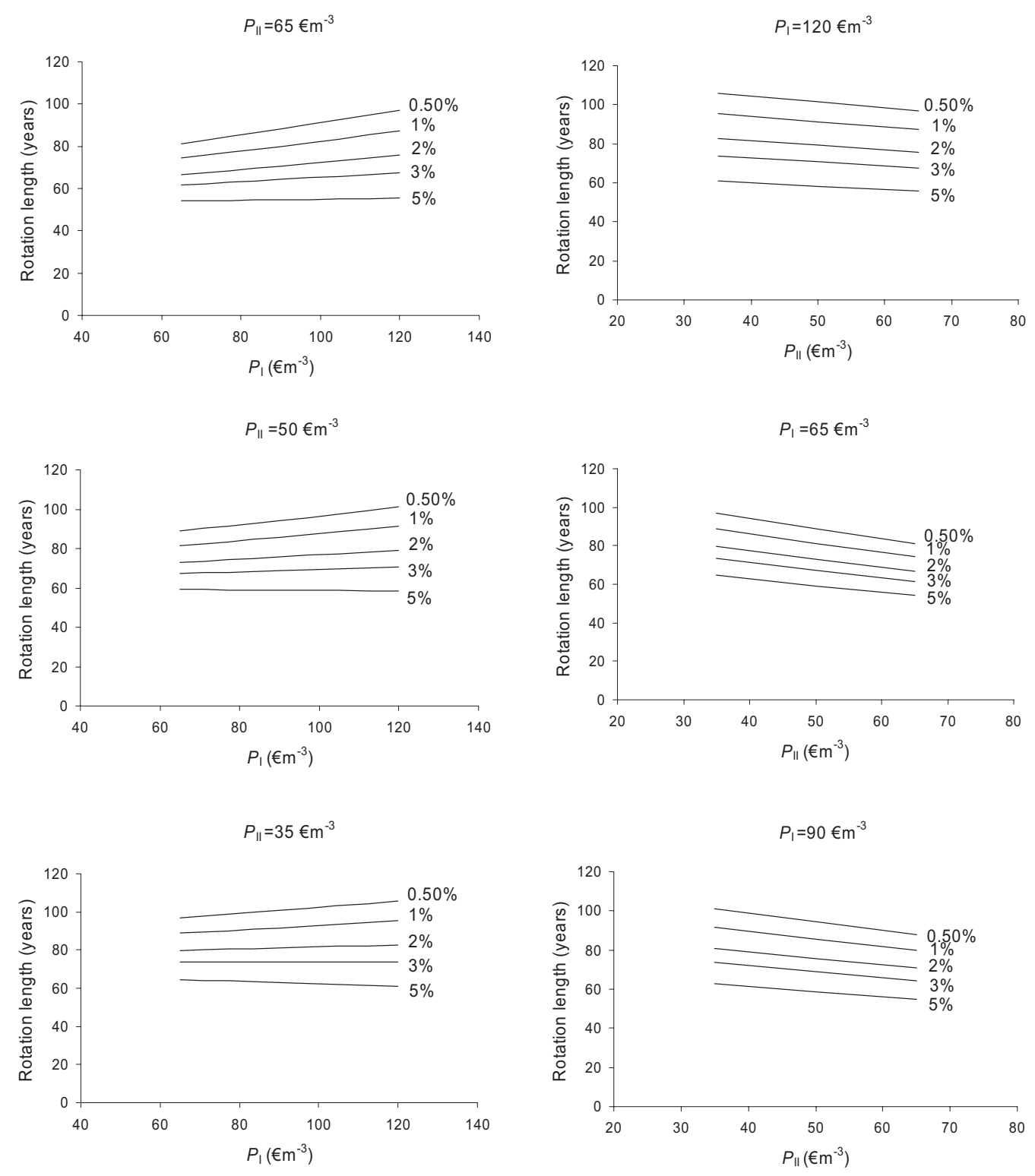

Figure 3. Effect of timber prices and discounting rate on the optimal rotation length when planting density is $2000 \mathrm{ha}^{-1}$ and site index is $18 \mathrm{~m}$.

calculating the pre- or post-thinning basal area for the first thinning, otherwise Fst is zero. As there were four thinnings in the optimal management schedules, results for the fourth thinning are obtained when all the dummy variables are zero.

Also these models include products of predictors which were found to have interaction. This is the case for discounting rate and age, the effect of discounting rate depending on the age of the stand: the older the stand is, the more increasing discounting rate decreases optimal pre-thinning stand basal area (see Fig. 4). The positive coefficient of $\ln (T)$ indicates that the basal area before certain thinning (e.g. the second) increases with stand age. However, age also affects through $T \times r$, with a consequence that the optimal pre-thinning basal area increases less with stand age when discounting rate increases (Fig. 4). Taking into account that the pre-thinning basal areas decrease when the number of the thinning increases (Tab. II and Fig. 4) the stand basal area should in most cases be decreased towards the end of the rotation.

The model also shows that better sites indexes have higher optimal pre-thinning basal areas, which is logical (see Fig. 5). Planting density does not affect the optimal pre-thinning basal area.

The price of grade III is not a significant predictor in this model but prices of grades I and II are. The higher is the price of grade I, the higher is the optimal pre-thinning basal area, which means that the thinning takes place later (Fig. 6). However, the price of grade I interacts with the price of grade II so that increasing price II decreases the effect of price I and the optimal pre-thinning basal area. For a given value of price I, higher values of price II lead to earlier thinnings. 
BEFORE FIRST THINNING

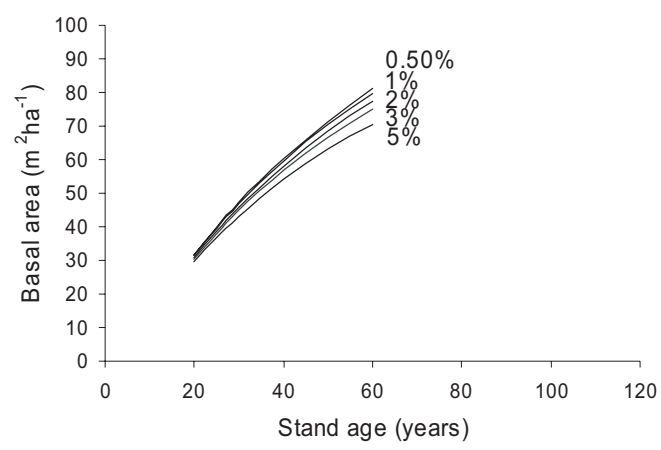

BEFORE SECOND THINNING

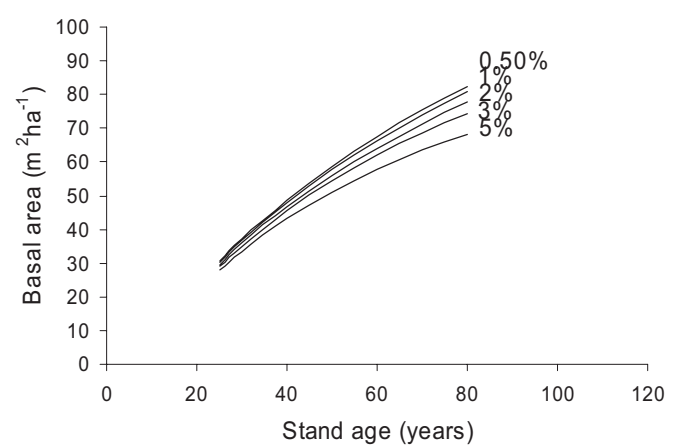

BEFORE THIRD THINNING

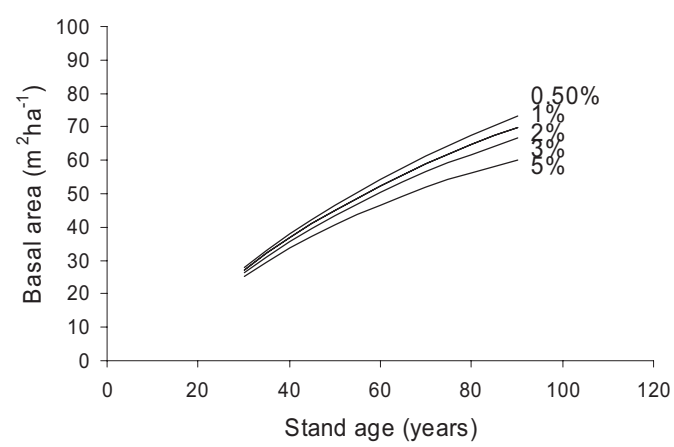

BEFORE FOURTH THINNING

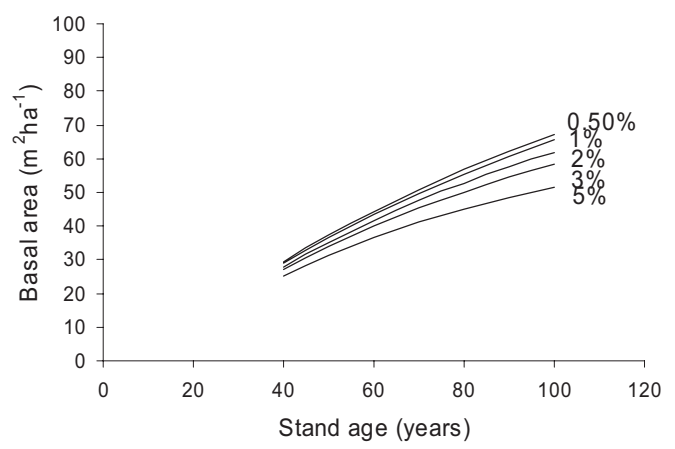

AFTER FIRST THINNING

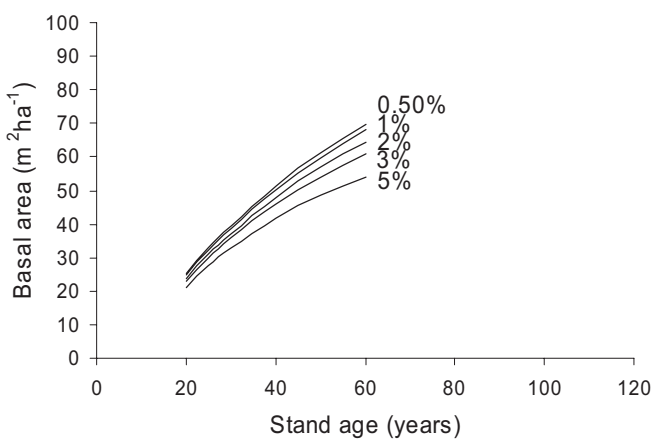

AFTER SECOND THINNING

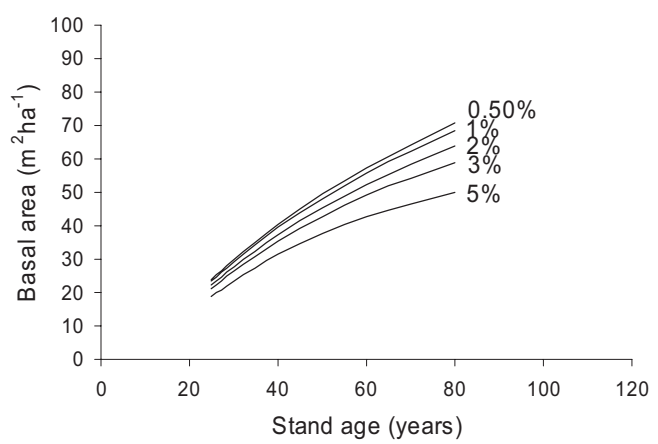

AFTER THIRD THINNING

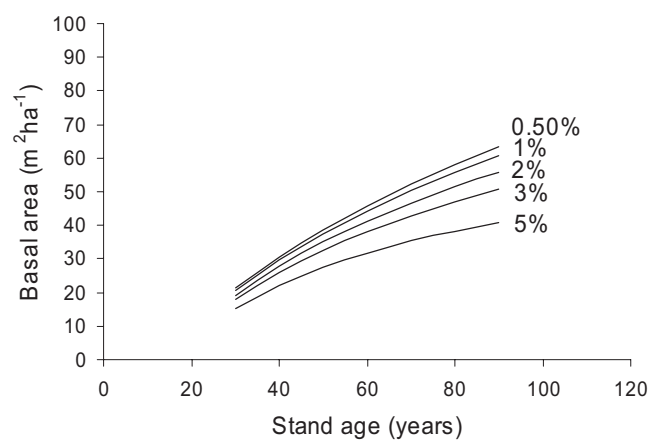

AFTER FOURTH THINNING

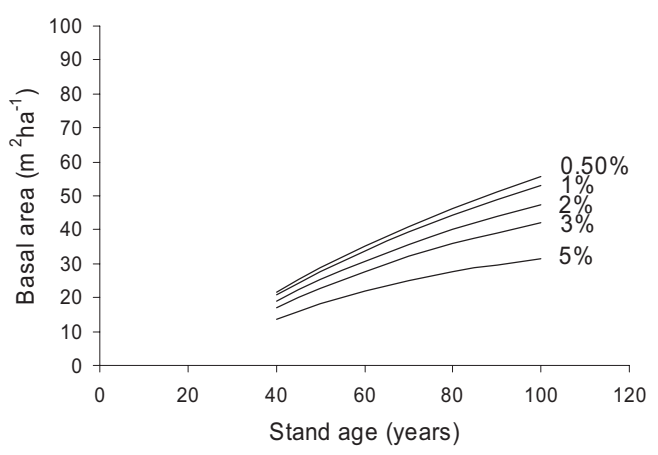

Figure 4. Effect of discounting rate on the optimal stand basal area before and after thinning when site index is $18 \mathrm{~m}$ and timber prices for grades I, II and III are 90,50 and $18 € \mathrm{~m}^{-3}$, respectively. 
BEFORE; $S I=6 \mathrm{~m}$

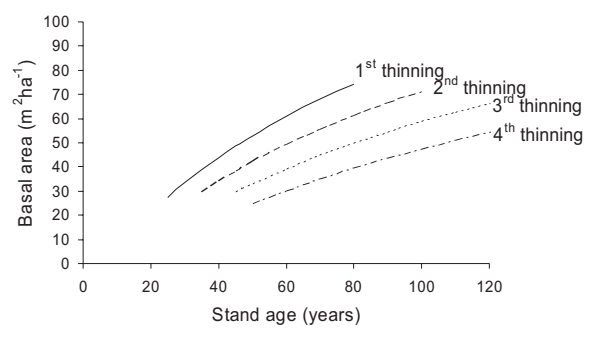

BEFORE; $S I=12 \mathrm{~m}$

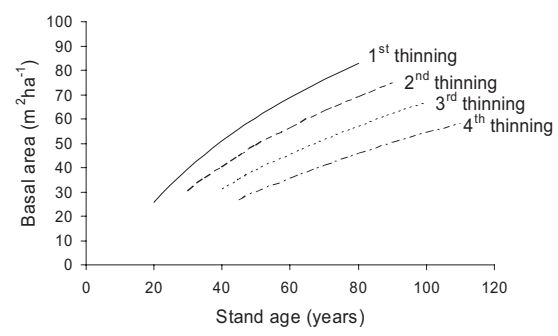

BEFORE; $S I=18 \mathrm{~m}$
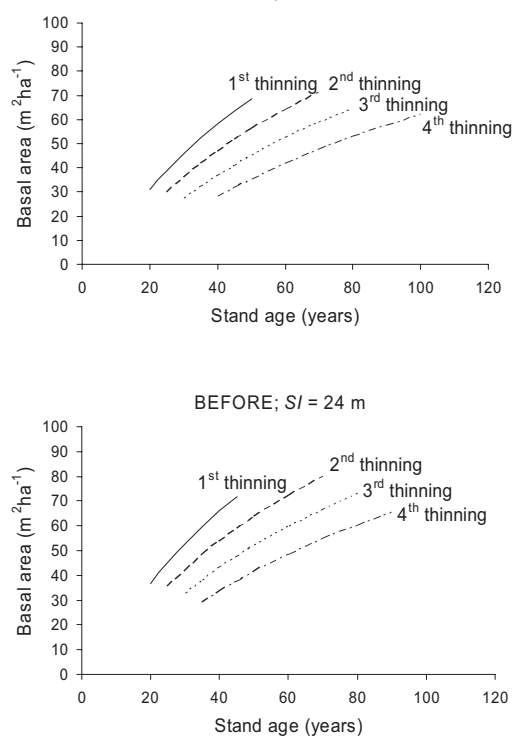

AFTER; $S I=6 \mathrm{~m}$

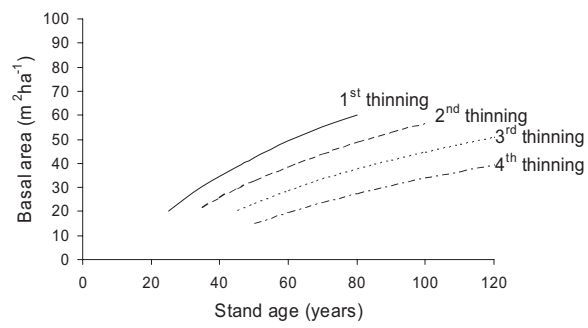

AFTER; $S I=12 \mathrm{~m}$

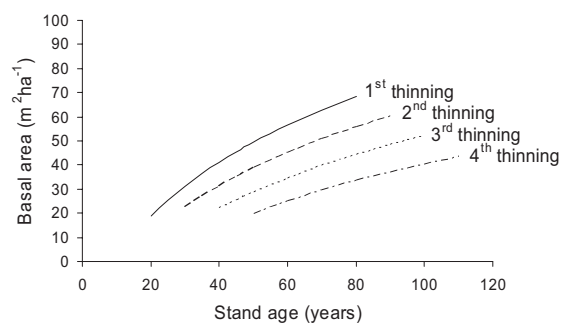

AFTER; $S I=18 \mathrm{~m}$
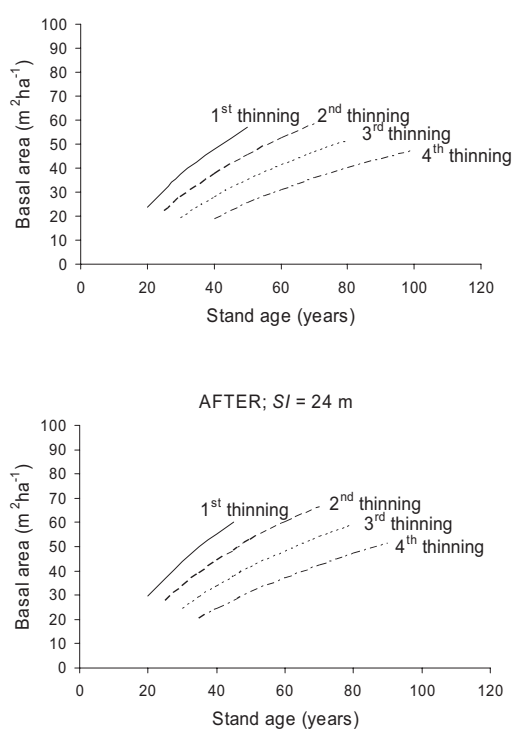

Figure 5. Basal area before and after thinning for different site indices with $2 \%$ discounting rate and timber prices for grades I, II and III are 90,50 and $18 € \mathrm{~m}^{-3}$, respectively.
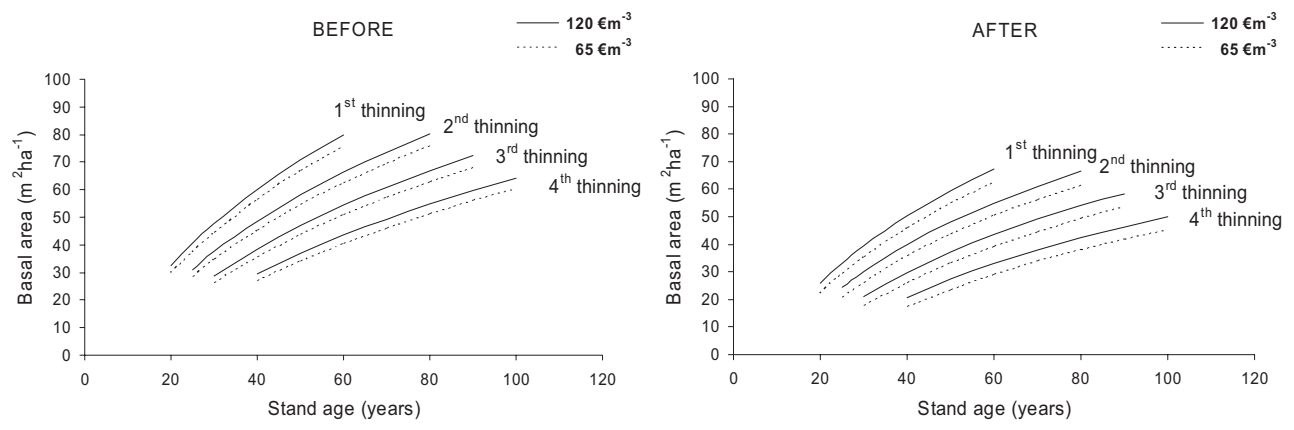

Figure 6. Effect of timber price of grade I on the stand basal area before and after thinning when discounting rate is $2 \%$, site index is $18 \mathrm{~m}$, and timber prices of grades II and III are 50 and $18 € \mathrm{~m}^{-3}$, respectively. 


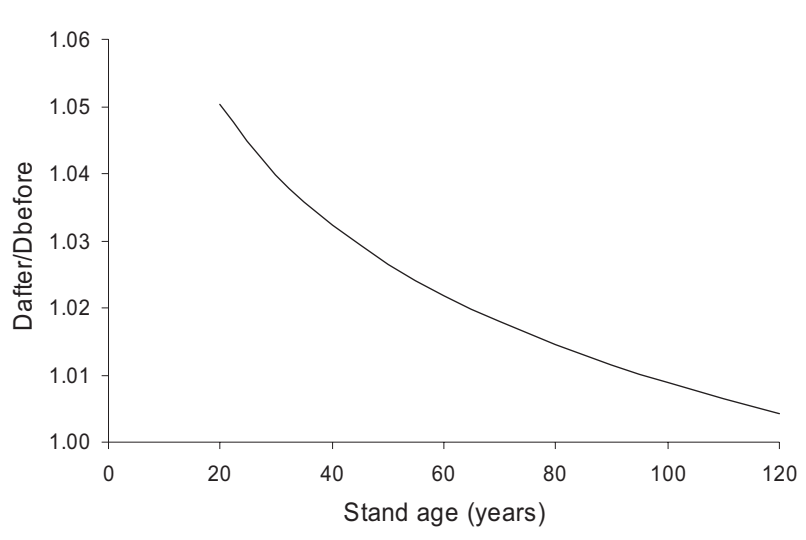

Figure 7. Correlation between stand age and the ratio of the mean diameter between post- and pre-thinning stand.

However, the effect of timber prices on the timing and intensity of thinnings is rather small.

The optimal basal area after thinning is strongly dependent on the basal area before thinning (Eq. (16), Tab. II). Other predictors are also included in the model, but their effect is much smaller. These predictors are the same as in the model for prethinning basal area. Therefore, for better site indices the basal area after thinning is higher than for the poorer ones (Fig. 4). Predictors $T \times r$ and $\ln (T)$ have the same effect as in the previous model. Stand basal area after a certain thinning, e.g. the first, increases with increasing age.

The ratio of the mean diameter between post- and prethinning stands $\left(D_{\text {after }} / D_{\text {before }}\right)$ was also studied. The mean value of the ratio between diameter after and before thinning was 1.03. This ratio correlates with several parameters, for instance with the stand age. At young ages thinnings tend to be low thinnings but as stand age increases the thinnings are more and more systematic (Fig. 7). The following equation describes this relationship:

$$
D_{\text {after }} / D_{\text {before }}=\exp (0.124-0.025 \ln (T))
$$

\section{DISCUSSION}

All the results of this study are based on the assumption that the growth and yield model developed for Dieguez-Aranda et al. [11] for even-aged Pinus sylvestris stands is correct and works properly. Therefore, it is important to remark that the model has some limitations in its application range due to the nature of the data used to build the model and the properties of the functions that composed it. The model was based on two measurements of 91 plots that represent stands ages between 15 and 55-60 years and site indices between 7 and $24 \mathrm{~m}$ at 40 years. The oldest plots were only 60 years old. Therefore our results are partly based on extrapolations of the models. However, these extrapolations are supposed to be reasonable because the functions used in growth and yield modelling are robust and widely tested and follow the overall patterns of stand development. Because well established and reasonably simple model forms were used in growth and yield modelling, it may be expected that no drastic deterioration in simulation

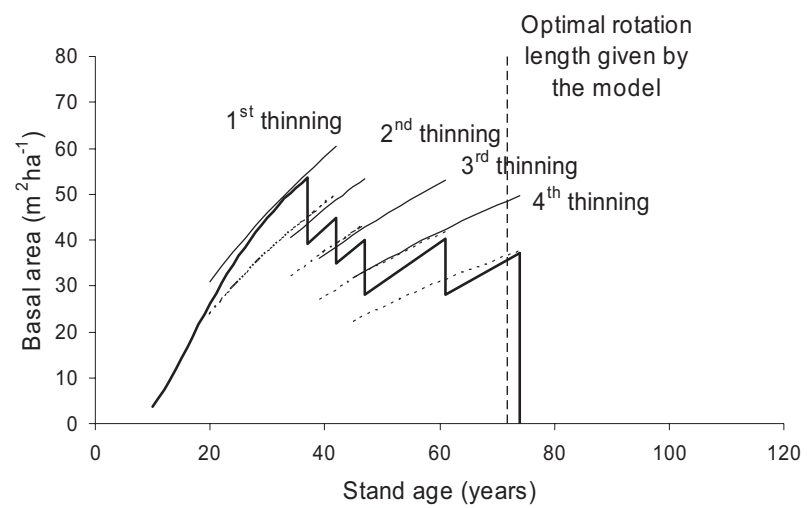

Figure 8. Comparison between the range of basal area before (thin solid line) and after (dashed line) thinning obtained from the model and the optimal management schedule (thick line) obtained in the optimisations for plantation density 1500 trees per hectare, discounting rate $2 \%$, site index $18 \mathrm{~m}$, and timber prices of grades I, II and III are 90,50 and $18 € \mathrm{~m}^{-3}$, respectively.

quality occurred when the limits of the modelling data were passed.

One shortcoming of the growth models is that they have been developed without taking into account the effect of thinnings on the growth of stand basal area. Therefore, the reliability of the projections done after thinning may be questioned. On the other hand, some studies on Scots pine suggest that the post-thinning growth of trees can be predicted reliably without using variables that describe the thinning [31]. In addition, the models that we used are the only available for Scots pine in Galicia.

Regarding the rotation length model, the first thing that attracts attention is the fact that, for certain combinations of economic and stand variables, much shorter rotations were obtained than the ones traditionally used. The results obtained show that for the very best soil qualities the optimal rotations vary between 42 and 99 years, depending on the plantation density, timber prices and discounting rates. For a discounting rate of $2 \%$ the rotation length varies between 52 and 77 years depending on plantation density and timber prices. When the discounting rate is 5\%, rotation lengths vary between 42 and 60 years depending also on the planting density and timber prices. For the poorest site index the rotations are between 73 and 170 years, depending again on the plantation density, timber prices and discounting rates. For instance, a $2 \%$ discounting rate would lead to rotation lengths between 90 and 133 and between 73 and 104 years for a 5\% discounting rate, in both cases depending on plantation density and timber prices.

With low discounting rates a good price of timber grade I led to long optimal rotations but with high discounting rates the optimal rotations shortened with improving price of grade I. This can be explained so that with high discounting rates the high opportunity cost of large trees dominates, whereas with lower rates the time matters less and improving price of large stems makes it worthwhile to wait until more trees reach large dimensions. 
FIRST THINNING

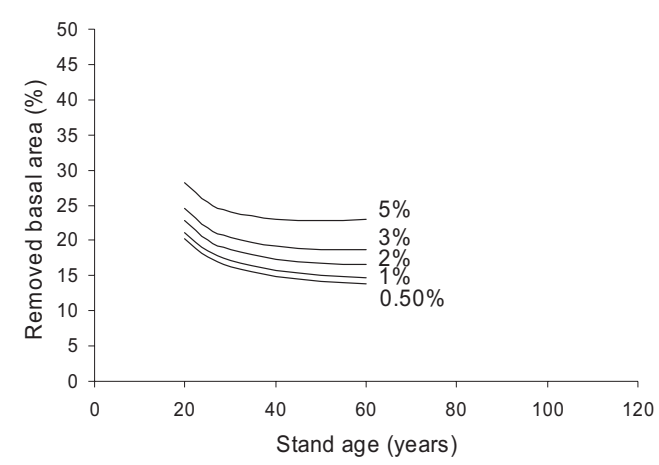

THIRD THINNING

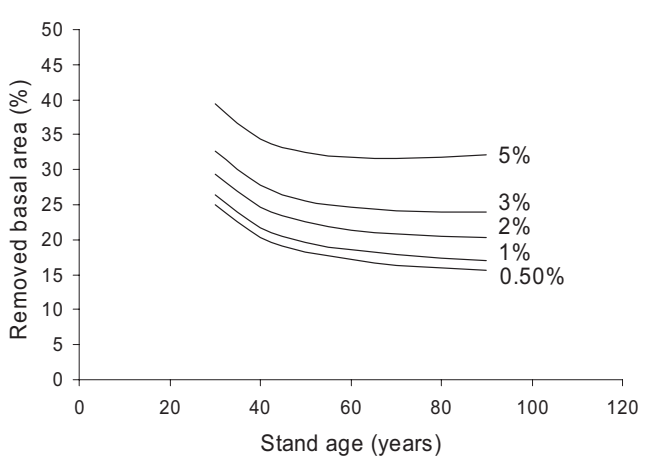

SECOND THINNING

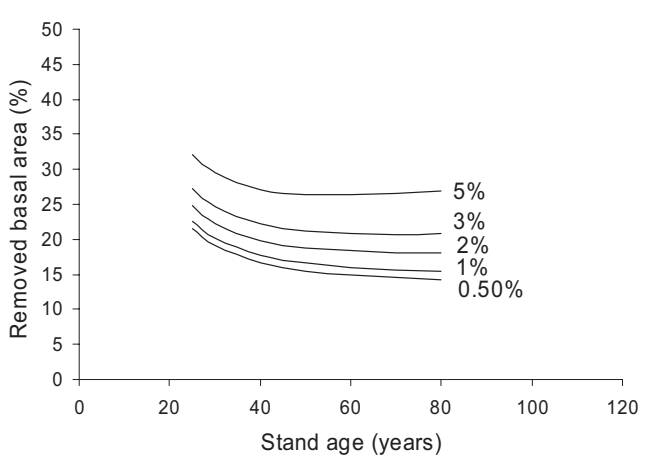

FOURTH THINNING

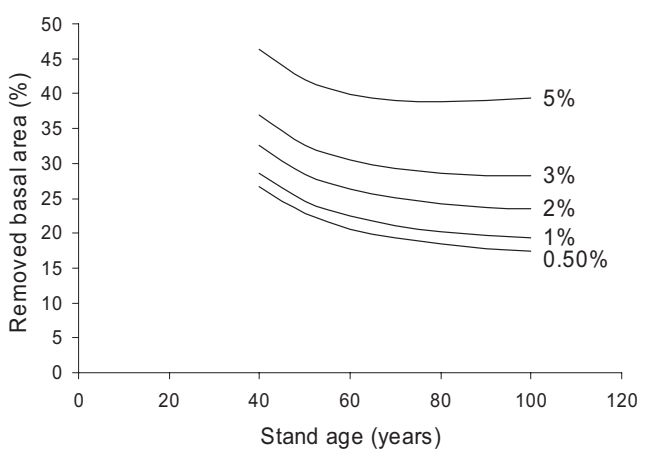

Figure 9. Dependence of thinning intensity on stand age and discounting rate when site index is $18 \mathrm{~m}$ and timber prices of grades I, II and III are 90,50 and $18 € \mathrm{~m}^{-3}$, respectively.

The optimal management schedules did not fit exactly with the graphs obtained by using the models (Fig. 8). One explanation may be that the optimisation algorithm does not always converge to the global optimum but to a local one that often is nearly as good as the global optimum. Rather different management schedules may lead to very similar soil expectation values. It can also happen that two quite different optimal management schedules are obtained with only a small change in site index, planting density, discounting rate, or timber price. These two schedules represent different strategies which are almost exactly good. This kind of high sensitivity of optimal management to economic parameters or stand characteristics decreases the fitting statistics of the models for optimal rotation and thinning basal area. Anyhow, the fitting statistics of the models are good despite these discrepancies, and the models guarantee, when used in forestry practise, that the timing and intensity of cuttings are always close to the optimum.

The pre- and post-thinning models can be also employed to compute the intensity of thinnings along the rotation of the stands. The graphs obtained (Fig. 9) show that the thinning intensity depends on the number of the thinning, the intensity increasing from the first thinning to the fourth. The intensity of the first thinning is around $20 \%$ of basal area, and in the fourth around 30\% of basal area. Furthermore, thinning intensity in- creases with the increment of discounting rate and decreases with the increasing age.

The results obtained in this study are quite similar to the ones that Palahí and Pukkala [25] obtained for even-aged Pinus sylvestris stands in Catalonia (north-eastern Spain). They optimised the management schedule using the same method, namely Hooke and Jeeves algorithm, and the same objective variable (LEV) as in the study. They found out that five thinnings were needed to maximise the LEV. The rotation lengths were longer than the ones achieved in the present study. These differences are due to the fact that the growth rates for Pinus sylvestris in Catalonia are much lower than in Galicia.

The models can be used in forestry practise as follows: the age of a stand is compared to the model for optimal rotation length (Eq. (14)). If the stand is older than the optimal rotation age, the stand is to be clear-felled. Otherwise the stand basal area is compared to the pre-thinning basal area given by Equation (15). If the stand basal area exceeds the model prediction, the stand should be thinned. The optimal post-thinning basal area is obtained from Equation (16). Various diagrams (e.g. Figs. 2 and 5) or software products can be prepared from the models to further ease their use in forestry practice.

Acknowledgements: The research reported in this paper was supported by Fundación Barrié de la Maza (Spain). 


\section{REFERENCES}

[1] Ambrosio Y., Tolosana E., Vignote S., El coste de los trabajos de aprovechamiento forestales como factor condicionante de la gestión forestal. Aplicación a las cortas de mejora en masas de pino silvestre, in: Rojo A. et al. (Eds.), Actas del Congreso de Ordenación y Gestión Sostenible de Montes. Santiago de Compostela, 4-9 de octubre 1999, edición CD.

[2] Arenas S.G., Rojo A., Cortas de mejora en repoblaciones de Pinus sylvestris L. de la Comarca Montaña de Lugo, in: Vignote S. (Ed.), Cortas de Mejora de las Masas Españolas: Selvicultura, Aprovechamientos y Comercialización de los Productos, Fundación Conde del Valle de Salazar, 1998, pp. 61-70.

[3] Bazaraa M.S., Shetty C.M., Nonlinear programming: theory and algorithms, John Wiley \& Sons, New York, 1979.

[4] Bravo F., Díaz-Balteiro L., Evaluation of new silvicultural alternatives for Scots pine stands in northern Spain, Ann. For. Sci. 61 (2004) 163-169.

[5] Clutter J.L., Fortson J.C., Pienaar L.V., Brister G.H., Bailey R.L., Timber management: a quantitative approach, John Wiley \& Sons, New York, 1983.

[6] DGCONA, Tercer Inventario Forestal Nacional (1.997-2.006): Galicia, Dirección General de Conservación de la Naturaleza, Ministerio de Medio Ambiente, Madrid, 2002.

[7] Díaz-Balteiro L., Romero C., Modelling timber harvest scheduling problems with multiple criteria: an application in Spain, For. Sci. 44 (1998) 47-57.

[8] Díaz-Balteiro L., Romero C., Forest management optimisation models when carbon captured is considered: a goal programming approach, For. Ecol. Manage. 174 (2003) 447-457.

[9] Díaz-Balteiro L., Álvarez Nieto A., Oria de Rueda Salgueiro J.A., Integración de la producción fúngica en la gestión forestal. Aplicación al monte "Urcido" (Zamora), Invest. Agrar.: Sist. Recur. For. 12 (2003) 5-19.

[10] Dieguez-Aranda U., Castedo Dorado F., Álvarez González J.G., Funciones de crecimiento en área basimétrica para masas de Pinus sylvestris L. procedentes de repoblación en Galicia, Invest. Agrar.: Sist. Recur. For. 14 (2005) 253-266.

[11] Dieguez-Aranda U., Castedo Dorado F., Álvarez González J.G., Rojo Alboreca A., Dynamic growth model for Scots pine (Pinus sylvestris L.) plantations in Galicia (north-western Spain), Ecol. Model. 191 (2006) 225-242.

[12] Fang Z., Borders B.E., Bailey R.L., Compatible volume-taper models for loblolly and slash pine based on a system with segmentedstem form factors, For. Sci. 46 (2000) 1-12.

[13] Gonzalez J.R., Pukkala T., Palahí M., Optimising the management of Pinus sylvestris L. stand under the risk of fire in Catalonia (northeast Spain), Ann. For. Sci. 62 (2005) 493-501.

[14] Hasenauer H., Burkhart H.E., Amateis R.L., Basal area development in thinned and unthinned loblolly pine plantations, Can. J. For. Res. 27 (1997) 265-271.

[15] Hooke R., Jeeves T.A., "Direct Search" solution of numerical and statistical problems, J. Assoc. Comput. Mach. 8 (1961) 212-229.

[16] Hyytiäinen K., Integrating economics and ecology in stand-level timber production, Finnish Forest Research Institute, Research Papers 908, 2003, 42 p.

[17] Kuliesis A., Saladis J., The effect of early thinning on the growth of pine and spruce stands, Baltic. For. 4 (1998) 8-16.

[18] Mäkinen H., Isomäki A., Thinning intensity and growth of Scots pine stands in Finland, For. Ecol. Manage. 201 (2004) 311-325.

[19] Mäkinen H., Isomäki A., Thinning intensity and long-term changes in increment and stem form of Scots pine trees, For. Ecol. Manage. 203 (2004) 21-34.
[20] Mäkinen H., Isomäki A., Hongisto T., Effect of half-systematic and systematic thinning on the increment of Scots pine and Norway spruce in Finland, Forestry 79 (2006) 103-121.

[21] Martínez E., Rodríguez-Soalleiro R., Rojo A., Análisis de la selvicultura desarrollada en los montes de Pinus sylvestris L. de Galicia. Perspectivas futuras, in: II Congreso Forestal Español, Irati, Gobierno de Navarra, Tomo IV, 1997, pp. 387-392.

[22] Miina J., Preparation of management models using simulation and optimisation, in: Pukkala T., Eerikäinen K. (Eds.), Tree seedling production and management of plantation forests, University of Joensuu, Faculty of Forestry, Research Notes 68, 1998, pp. 165180.

[23] Møller C.M., The influence of thinning on volume growth. Part I, in: Heiberg S.O. (Ed.), Thinning problems and practise in Denmark, Technical Publication No. 76, State University of New York, College of Forestry, 1954, pp. 5-32.

[24] Montero G., Cañellas I., Ortega C., Del Río M., Results from a thinning experiment in a Scots pine (Pinus sylvestris L.) natural regeneration stand in the Sistema Ibérico mountain range (Spain), For. Ecol. Manage. 145 (2001) 151-161.

[25] Palahí M., Pukkala T., Optimising the management of Scots pine (Pinus sylvestris L.) stands in Spain based on individual-tree models, Ann. For. Sci. 60 (2003) 105-114.

[26] Petterson N., The effect of density after precommercial thinnings on volume and structure in Pinus sylvestris and Picea abies stands, Scand. J. For. Res. 8 (1993) 528-539.

[27] Pukkala T., Puun hinta ja taloudellisesti optimaalinen hakkuun ajankohta, Metsätieteen aikakauskirja 1 (2006) 33-48.

[28] Pukkala T., Mabvurira D., Optimising the management of Eucalyptus grandis plantations in Zimbabwe. in: Pukkala T., Eerikäinen K. (Eds.), Growth and yield modelling of tree plantations in South and East Africa, University of Joensuu, Faculty of Forestry, Research Notes 97, 1999, pp. 113-123.

[29] Pukkala T., Miina J., Kellomäki S., Response to different thinning intensities in young Pinus sylvestris, Scand. J. For. Res. 13 (1998) $141-150$.

[30] Pukkala T., Miina J., Rautianen O., Dependence of stand management on management goal, in: Pukkala T., Eerikäinen K. (Eds.), Tree seedling production and management of plantation forest, University of Joensuu, Faculty of Forestry, Research Notes 68, 1998, pp. 165-180.

[31] Pukkala T., Miina J., Palahí M., Thinning response and thinning bias in a young Scots pine stand, Silva Fenn. 36 (2002) 827-840.

[32] Rodriguez-Soalleiro R., Vega P., Apuntes de selvicultura de zonas atlánticas, Unicopia, Lugo, Spain, 1998.

[33] Rojo A., Diéguez-Aranda U., Rodríguez Soalleiro R., Gadow K.v., Modelling silvicultural and economic alternatives for Scots pine (Pinus sylvestris L.) plantations in north-western Spain, Forestry 78 (2005) 385-401.

[34] Salminen H., Varmola M., Development of Scots pine stands from precommercial thinning to first commercial thinning, Folia Forestalia 752 (1990) (in Finnish with English summary).

[35] Trasobares A., Pukkala T., Optimising the management of unevenaged Pinus sylvestris L. and Pinus nigra Arn. mixed stands in Catalonia, north-east Spain, Ann. For. Sci. 61 (2004) 747-758.

[36] Valsta L.T., Stand management optimization based on growth simulators, The Finnish Forest Research Institute, Research Papers 453, 1993, pp. 51-81.

[37] Varmola M., Salminen H., Timing and intensity of precommercial thinning in Pinus sylvestris stands, Scand. J. For. Res. 19 (2004) $142-151$.

[38] Xunta de Galicia, O monte galego en cifras, Dirección Xeral de Montes e Medio Ambiente Natural, Santiago de Compostela, 2001.

[39] Xunta de Galicia, Anuario de Estatística Agraria 2003, Consellería de Medio Rural, 2006. 